\title{
Chronic urinary retention due to diabetic cystopathy masquedering as mesenteric cyst
}

\author{
Siddharth Pandey, Gaurav Garg, Ajay Aggarwal, Deepanshu Sharma
}

Department of Urology, King George's Medical University, Lucknow, Uttar Pradesh, India

Correspondence to

Dr Gaurav Garg,

gougarg@gmail.com

Accepted 7 September 2018

Check for updates

(c) BMJ Publishing Group Limited 2018. No commercial re-use. See rights and permissions. Published by BMJ.

To cite: Pandey S, Garg G, Aggarwal A, et al. BMJ Case Rep Published Online First: [please include Day Month Year]. doi:10.1136/bcr-2018 226575

\section{DESCRIPTION}

A 55-year-old previously diabetic man presented with progressive abdominal distension for the last threemonths. He denied any bowel/bladder complaints. His medical/surgical history was unremarkable. On examination his vitals were stable and a huge abdominal mass $(10 \times 11 \mathrm{~cm})$ was palpable. The mass was having side-to-side mobility. There was no hepatosplenomegaly or clinically significant lymphadenoapathy. On evaluation with ultrasonography of abdomen and CT scan, there was evidence of huge, cystic and homogenous mass $(13 \times 11 \mathrm{~cm})$ with clear margins occupying almost entire abdominal cavity (figure 1). There was no evidence of calcification, septations or nodules in the mass, and it appeared to be separate from both the kidneys and bowel. A provisional diagnosis of mesenteric cyst was made, and the patient was taken for laparotomy. A per-urethral catheter was placed intraoperatively and surgery was started. During laparotomy it came as an element of surprise that the swelling was actually chronically distended bladder and not mesenteric cyst. Subsequently, cystoscopy was done which revealed large capacity bladder ( $>2 \mathrm{~L}$ ), high bladder neck with multiple trabeculations. Also a cystometrogram (CMG) was done 1 week after the laparotomy, which showed hypocontractile bladder with a low-pressure low-flow pattern. The patient

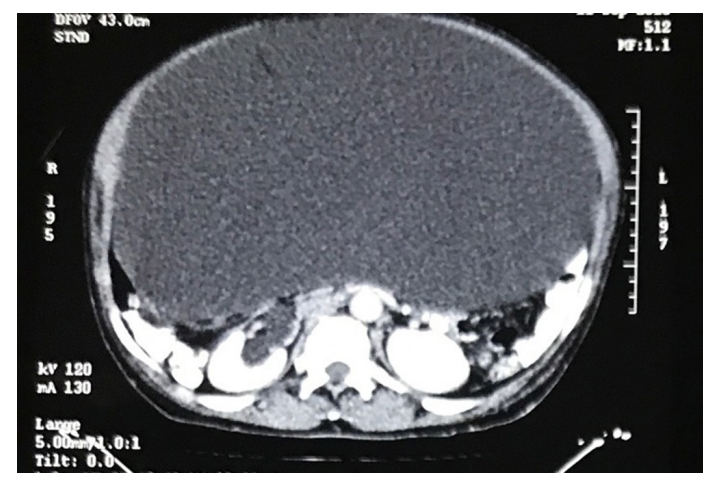

Figure 1 CT scan image of patient depicting a huge, cystic and homogenous intra-abdominal mass with clear margins occupying almost entire abdomen. was managed with bladder neck incision and regular clean intermittent catheterisation (CIC) in the postoperative period. The patient is doing fine on CIC on 6-month follow-up. Bladder cystopathy due to diabetes mellitus can occur in around $25 \%-90 \%$ cases. $^{1}$ In patients with long-standing diabetics factors like decreased bladder sensation, poor bladder contractility and impaired bladder emptying can lead to insidious urinary retention. ${ }^{2}$ The management of patients with diabetic cystopathy depends on clinical symptoms and $\mathrm{CMG}$ findings. ${ }^{3}$ Treatment measures include scheduled voiding, cholinergics and surgical treatment of concomitant bladder neck obstruction. ${ }^{3}$

\section{Learning points}

- In patients with diabetes, chronic urinary retention may occur due to diabetic cystopathy.

- A hugely enlarged bladder may mimic other intra-abdominal lumps like mesenteric cyst.

- Management of patients with diabetic cystopathy depends on clinical symptoms and cystometrogram findings.

Contributors GG: concept, design, supervision, processing, writing manuscript and critical analysis. SP: concept, design, supervision, processing, writing manuscript and critical analysis. AA: supervision, processing, writing manuscript and critical analysis. DS: supervision, processing, writing manuscript and critical analysis.

Funding The authors have not declared a specific grant for this research from any funding agency in the public, commercial or not-for-profit sectors.

Competing interests None declared.

Patient consent Obtained.

Provenance and peer review Not commissioned; externally peer reviewed.

\section{REFERENCES}

1 Frimodt-Møller C. Diabetic cystopathy: epidemiology and related disorders. Ann Intern Med 1980;92(2 Pt 2):318-21.

2 Lee WC, Wu HP, Tai TY, et al. Effects of diabetes on female voiding behavior. J Urol 2004:172:989-92.

3 Yuan Z, Tang Z, He C, et al. Diabetic cystopathy: a review. J Diabetes 2015:7:442-7. 
Copyright 2018 BMJ Publishing Group. All rights reserved. For permission to reuse any of this content visit http://group.bmj.com/group/rights-licensing/permissions.

BMJ Case Report Fellows may re-use this article for personal use and teaching without any further permission.

Become a Fellow of BMJ Case Reports today and you can:

- Submit as many cases as you like

- Enjoy fast sympathetic peer review and rapid publication of accepted articles

Access all the published articles

- Re-use any of the published material for personal use and teaching without further permission

For information on Institutional Fellowships contact consortiasales@bmjgroup.com

Visit casereports.bmj.com for more articles like this and to become a Fellow 